\title{
Penanganan Intoleransi Oleh Pemerintah \\ Daerah Istimewa Yogyakarta
}

\author{
Muhamad Rusdi \\ Fakultas Hukum Universitas Widya Mataram \\ Dalem Mangkubumen KT III/ 237 Yogyakarta \\ Email: rusdi.rs@gmail.com
}

\begin{abstract}
Abstrak
Masalah intoleransi seringkali mengganggu kehidupan berbangsa dan bernegara sehingga, masalah semacam ini harus di tangani sedini mungkin agar tidak menyebar dan mempengaruhi kehidupan masyarakat. Maka, Instruksi Gubernur DIY Nomor 1/INSTR/2019 tentang Pencegahan Potensi Konflik Sosial, menjadi suatu solusi untuk menangani masalah-masalah Intoleransi yang seringkali terjadi di Yogyakarta. Setidaknya karena dipicu oleh dua hal yaitu: pertama, keberadaan intoleransi masih ada dan seringkali muncul dengan jarak yang berdekatan. Kedua, hingga saat ini belum ada tindak lanjut dari Instruksi Gubernur DIY terkait pencegahan potensi konflik sosial. Maka, penelitian ini bertujuan menemukan persoalan yuridis dengan penelitian normatif deskriptif, melaluui pendekatan politik hukum dan Hak Asasi Manusia (HAM).
\end{abstract}

Kata kunci: Intoleransi, Konflik Sosial, Penanganan

\begin{abstract}
The problem of intolerance oftenly bothers nation-state life, therefore the problem like this must be coped from earliest days, so it doesn't overspread and influence people's lives. Thus, the instruction of Governon of DIY Number 1/INSTR/2019 about Potencial Prevention of Social Conflict is a solution to cope the problems of intolerance which is happened in Yogyakarta oftenly. At least, it's triggered by two things: first, intolerance still exists and appears in a rapid time. Second, it hasn't follow up so far by the instruction of Governon of DIY about Potencial Prevention of Social Conflict.Therefore, the purpose of this research to find the juridical problem by using normative and descriptive research, by legal politic and human right approach.
\end{abstract}

Keywords: Intolerance, Social Conflict, Handling

\section{A. Pendahuluan}

Hubungan antar manusia disuatu negara menjadi tanggungjawab negara itu sendiri karena, negara baik secara tidak langsung maupun langsung telah mendapatkan legitimasi oleh rakyat untuk memberikan jaminan sosial. Jaminan sosial merupakan instrumen rakyat untuk hidup dengan aman, damai dan sejahtera sebagaimana cita-cita bangsa Indonesia. Cita-cita bangsa sebagaimana dimaksud harus jelas sehingga, jaminan sosial yang telah menjadi salah satu butir dalam Pancasila (keadilan sosial bagi seluruh rakyat) menjadi pedoman negara agar serius mendistribusikan keadilan sosial bagi seluruh rakyat indonesia.

Hubungan sosial dalam kehidupan masyarakat seringkali justru menghambat adanya jaminan sosial sehingga, keadilan sosial yang telah menjadi cita-cita bangsa Indonesia seringkali justru terhambat karena adanya suatu pilihan seseorang atau sekelompok orang yang berbeda dengan yang lainnya. Misalnya, munculnya intoleransi yang seringkali disematkan dengan agama tertentu. Masalah ini tentu membutuhkan instrumen yang dapat dijadikan acuan dalam suatu negara yaitu, acuan yang sangat relevan adalah Pancasila yang diantara butir atau sila pertama yang mengatur 
"Ketuhanan Yang Maha Esa" perlu menjadi perilaku (tidak hanya teks yang dihapal) berbangsa dan bernegara.

Sila-sila yang terdapat dalam Pancasila tersebut kemudian diuraikan melalui Undang-Undang Dasar 1945. Diantara Pasal yang dapat dijadikan acuan adalah, Pasal 29 ayat (1) UUD 1945 menyebutkan; "Negara berdasar atas Ketuhanan Yang Maha Esa", ayat (2) "Negara menjamin kemerdekaan tiap-tiap penduduk untuk memeluk agamanya masing-masing dan untuk beribadah menurut agamanya dan kepercayaannya itu". Jaminan dalam UUD 1945 inilah yang kemudian diuraikan secara lebih rinci melalui peraturan perundang-undangan, diantaranya adalah Penetapan Presiden Nomor 1 Tahun 1965 tentang Pencegahan Penyalahgunaan dan/atau Penodaan Agama. Pada pasal 1 (Penetapan Presiden Nomor 1 Tahun 1965) menyebutkan; "Setiap orang dilarang dengan sengaja di muka umum menceritakan, menganjurkan atau mengusahakan dukungan umum, untuk melakukan penafsiran tentang sesuatu agama yang dianut di Indonesia atau melakukan kegiatan-kegiatan keagamaan yang menyerupai kegiatan-kegiatan keagamaan dari agama itu, penafsiran dan kegiatan mana menyimpang dari pokok-pokok ajaran agama itu". Pelanggaran pidana dapat dijatuhkan dengan hukuman lima tahun apabila: ${ }^{1}$ pertama, mengungkapkan dimuka umum yang bersifat permusuhan, penyalahgunaan atau penodaan terhadap suatu agama yang dianut di Indonesia. Kedua, ungkapan yang dimaksud agar supaya orang tidak menganut agama apapun juga, yang bersendikan ke-Tuhanan Yang Maha Esa."

Di tingkat daerah, Penganan konflik sosial yang terjadi di Yogyakarta mengacu terhadap Instruksi Gubernur DIY Nomor 1/INSTR/2019 tentang Pencegahan Potensi Konflik Sosial, bertujuan untuk menjaga situasi keamanan, ketentraman, ketertiban dan kedamaian di wilayah Daerah Istimewa Yogyakarta sebagai wujud tanggung jawab Pemerintah Daerah dalam memenuhi hak-hak asasi Masyarakat. Intruksi tersebut kemudian ditujukan kepada, Bupati/Walikota seDaerah Istimewa Yogyakarta untuk ikut mencegah adanya intoleransi di DIY. Isi dari intruksi tersebut diantaranya adalah; Pertama: Melakukan upaya-upaya pencegahan praktik diskriminasi dan menjunjung tinggi sikap saling menghormati serta menjaga kerukunan hidup beragama dan aliran kepercayaan. Kedua: Melakukan upaya-upaya pencegahan dengan merespon secara cepat dan tepat semua permasalahan di dalam masyarakat yang berpotensi menimbulkan intoleran dan/atau potensi konflik sosial, guna mencegah lebih dini tindak kekerasan.

Dikeluarkannya Intruksi Gubernur tersebut dilatarbelakangi oleh beberapa kejadian yang menyebabkan adanya konflik sosial di Yogyakarta misalnya, Seorang seniman bernama Slamet Jumiarto beserta istri dan kedua anaknya ditolak untuk bermukim di RT 08, Pedukuhan Karet, Pleret, Bantul. Alasan penolakan Slamet tinggal di wilayah itu lantaran Slamet

\footnotetext{
1 Pasal 156a PNPS Nomor 1 Tahun 1965
} 
beragama Kristen. Dari hasil mediasi yang dilakukan, sebagian warga tak keberatan Slamet tinggal di wilayahnya. Namun Kepala Pedukuhan Karet bersikeras menolaknya dan hanya mengizinkan Slamet tinggal selama 6 bulan saja. Penolakan tersebut menurut Kepala Pedukuhan Karet Iswanto didasarkan atas Surat Keputusan nomor 03/POKGIAT/Krt?Plt/X/2015, dimana dalam surat keputusan itu tertulis bahwa pendatang baru harus beragama Islam, sama dengan agama yang dianut oleh mayoritas penduduk. Peraturan ini pun akhirnya dicabut pascapenolakan terhadap Slamet. Pencabutan aturan dilakukan pada 2 April 2019. ${ }^{2}$

Secara normatif berdasarkan peraturan perundang-undangan maka, Surat Keputusan Nomor 03/POKGIAT/Krt?Plt/X/2015 tersebut bertentangan dengan intruksi Gubernur DIY yaitu Instruksi Gubernur DIY Nomor 1/INSTR/2019 tentang Pencegahan Potensi Konflik Sosial. Sehingga, masalah-masalah intoleransi yang terjadi di Yogyakarta dengan adanya intruksi tersebut akan meminimalisir adanya kasus-kasus intoleransi di DIY. Adapun rumusan masalah dalam penelitian ini yaitu, 1) Apa yang menyebabkan terjadinya intoleransi di Yogyakarta?; 2) Bagaimana Tindak Lanjut Intruksi Gubernur Daerah Istimewa Yogyakarta dalam Menangani Tindakan Intoleransi di Yogyakarta?. Kemudian tujuan dari tulisan dari karya ilmiah ini adalah untuk mengetahui apa saja penyebab terjadinya intoleransi di Daerah Istimewa Yogyakarta dan Peran Gubernur Daerah Istimewa Yogyakarta dalam Menangani Tindakan Intoleransi di Yogyakarta, serta bagaimana efektivitas dari penerapan Intruksi Gubernur dalam menangani tindakan intoleransi.

\section{B. Telaah Konsep}

Secara konseptual, intoleransi merupakan suatu tindakan yang dilakukan oleh seseorang atau sekelompok orang yang dapat mengganggu dan meresahkan orang lain atau kelompok lain, dan tindakan tersebut bertentangan dengan peraturan perundang-undangan yang berlaku di Indonesia. Tindakan-tindakan intoleransi sebagaimana disebut seringkali terjadi di Yogyakarrta sehingga, membutuhkan penanganan khusus dari pemerintah Daerah Istimewa Yogyakarta agar, tindakan tersebut dapat berkurang dan tidak menyebar luas di Yogyakarta.

Ketentuan mengenai larangan melakukan tindakan intoleransi terkait agam dan kepercayaan telah diatur dalam Pasal 29 ayat (1) UUD 1945 menyebutkan; "Negara berdasar atas Ketuhanan Yang Maha Esa”, ayat (2) "Negara menjamin kemerdekaan tiap-tiap penduduk untuk memeluk agamanya masing-masing dan untuk beribadah menurut agamanya dan kepercayaannya

\footnotetext{
2 https://www.suara.com/news/2019/04/03/163344/salib-dipotong-hingga-tolak-sedekah-laut-4kasus-intoleransi-di-yogyakarta, Diakses 12 November, 2019
} 
itu". Dengan ketentuan tersebut maka, setiap penduduk diperbolehkan atau mempunyai hak untuk memeluk agama yang diyakini oleh dirinya atau kelompoknya serta dapat melakukan ibadah sesuai dengan agama yang dianutnya. Kemudian ketentuan ini diuraikan lebih detail melalui undangundang organik yaitu dalam Penetapan Presiden Nomor 1 Tahun 1965 tentang Pencegahan Penyalahgunaan dan/atau Penodaan Agama. Pada pasal 1 (Penetapan Presiden Nomor 1 Tahun 1965) menyebutkan; "Setiap orang dilarang dengan sengaja di muka umum menceritakan, menganjurkan atau mengusahakan dukungan umum, untuk melakukan penafsiran tentang sesuatu agama yang dianut di Indonesia atau melakukan kegiatan-kegiatan keagamaan yang menyerupai kegiatan-kegiatan keagamaan dari agama itu, penafsiran dan kegiatan mana menyimpang dari pokok-pokok ajaran agama itu".

Di tingkat daerah, Penganan konflik sosial yang terjadi di Yogyakarta mengacu terhadap Instruksi Gubernur DIY Nomor 1/INSTR/2019 tentang Pencegahan Potensi Konflik Sosial, bertujuan untuk menjaga situasi keamanan, ketentraman, ketertiban dan kedamaian di wilayah Daerah Istimewa Yogyakarta sebagai wujud tanggung jawab Pemerintah Daerah dalam memenuhi hak-hak asasi Masyarakat. Adapun isi instruksi Gubernur DIY Nomor 1/INSTR/2019 tentang Pencegahan Potensi Konflik Sosial: Dalam rangka menjaga situasi keamanan, ketentraman, ketertiban dan kedamaian di wilayah Daerah Istimewa Yogyakarta sebagai wujud tanggung jawab Pemerintah Daerah dalam memenuhi hak-hak asasi Masyarakat, dengan ini menginstruksikan : Kepada : Bupati/Walikota se-Daerah Istimewa Yogyakarta Untuk : KESATU: Melakukan pembinaan dan pengawasan dalam rangka mewujudkan kebebasan beragama dan beribadat menurut agama dan keyakinanya, memilih pendidikan dan pengajaran, memilih pekerjaan dan bertempat tinggal. KEDUA: Melakukan upaya-upaya pencegahan praktik diskriminasi dan menjunjung tinggi sikap saling menghormati serta menjaga kerukunan hidup beragama dan aliran kepercayaan.

KETIGA: Melakukan upaya-upaya pencegahan dengan merespon secara cepat dan tepat semua permasalahan di dalam masyarakat yang berpotensi menimbulkan intoleran dan/atau potensi konflik sosial, guna mencegah lebih dini tindak kekerasan. KEEMPAT: Meningkatkan efektivitas pencegahan potensi intoleran dan/atau potensi konflik sosial, secara terpadu, sesuai tugas, fungsi dan kewenangan masing-masing berdasarkan peraturan perundang-undangan. KELIMA: Mengambil langkah-langkah cepat,tepat, tegas dan proporsional berdasarkan peraturan perundang-undangan dan menghormati nilai-nilai hak asasi manusia untuk menghentikan segala bentuk tindak kekerasan akibat intoleran dan/atau potensi konflik sosial. KEENAM: Menyelesaikan berbagai permasalahan yang disebabkan oleh Suku, Agama, Ras, Antar Golongan 
(SARA) dan politik yang timbul dalam masyarakat dengan menguraikan dan menuntaskan akar masalahnya.

KETUJUH: Melakukan pembinaan dan pengawasan terhadap pelaksanaan penanganan konflik sosial sebagaimana diatur dalam Peraturan Gubernur Daerah Istimewa Yogyakarta Nomor 107 Tahun 2015 Tentang Penanaganan Konflik Sosial, kepada organisasi perangkat daerah, kepala desa sampai dengan masyarakat di lingkungan kabupaten/kota. KEDELAPAN: Segala bentuk keputusan/kebijakan agar disesuaikan dengan intruksi gubernur ini. Instruksi Gubernur ini mulai berlaku pada tanggal ditetapkan 4 April 2019.

\section{Metode Penelitian}

Obyek penelitian ini adalah peraturan perundang-undangan yang mengatur tentang larangan terhadap tindakan intoleransi, terutama peraturan perundang undang-undangan yang berlaku di Daerah Istimewa Yogyakarta.

Sumber data dalam penelitian ini menggunakan studi hukum normatif, yaitu bahan yang digunakan adalah bahan pustaka atau data sekunder yang mencakup bahan hukum primer, bahan hukum sekunder dan bahan hukum tersier. Adapun bahan-bahan penelitian sebagaimana dimaksud.

Teknik pengumpulan data dan metode pendekatan dengan mengkaji mengenai pokok permasalahan melalui pendekatan yuridis-normatif. Identifikasi masalah yang ada secara detail yang bersumber dari beberapa aspek. Baik berupa data yang bersumber dari literatur buku, jurnal, serta perundang-undangan yang relevan.

Analisis data digunakan untuk melakukan pengkajian lebih mendalam mengenai data-data yang ada terkait sajian data Intoleransi dan peraturan perundang-undangan. Karena penelitian ini menggunakan penelitian pustaka dengan pendekatan perundang-undangan maka, bahan hukum primer, sekunder dan tersier menjadi bahan utama untuk dikaji lebih mendalam.

\section{Pembahasan}

\section{Dinamika Problem Intoleransi}

Persoalan intoleransi sebenarnya terjadi dibeberapa daerah namun, pada konteks Yogyakarta kejadian tersebut masih seringkali muncul sehingga harus menjadi perhatian bersama terutama pemerintah dalam menangani persoalan tersebut. Masyarakat dan pemerintah harus menjadikan Pancasila sebagai acuan untuk mengikis persoalan intoleransi, hal yang demikian itu supaya semakin memperkuat kecintaan masyarakat akan kesatuan dan sadar akan variasi kebudayaan dan kepercayaan di Indonesia. 
Pemerintah menurutnya pada tahun 2014 tidak banyak membantu menyelesaikan persoalan KBB yang terjadi dibeberapa daerah, bahkan terkesan membiarkan masalah dengan melakukan pembiaran terhadap regulasi yang meminggirkan kelompok minoritas semacam Ahmadiyah dan Syiah. Kebijakan lain misalnya yang berkaitan dengan hak sipil berupa penolakan dari KUA untuk menikahkan pasangan Ahmadiyah kecuali mereka menyatakan bertaubat, memeluk Islam arus utama. KUA di Kecamatan Jalaksana Kuningan menolak menikahkan warga Ahmadiyah dengan alasan Ahmadiyah adalah aliran sesat. Mereka baru bersedia menikahkan warga Ahmadiyah jika mereka bersedia menandatangani surat pernyataan keluar dari Ahmadiyah. ${ }^{3}$

Persoalan lainnya terkait kebijakan KTP, Dinas Catatan Sipil dan Kependudukan Kabupaten Kuningan hingga saat ini belum memberikan e-KTP kepada ratusan warga Ahmadiyah Manislor, Kuningan. Padahal warga di desa lainnya hampir semuanya mendapat e-KTP. Menurut Kepala Dinas, ada tekanan dari ormas Islam di Kuningan terhadap Kepala Dinas sehingga tidak dapat mengeluarkan e-KTP kelompok Ahmadiyah. Padahal, e-KTP ini merupakan hak setiap warga negara dan merupakan alat mengkau dalam menikmati hak sosial-politik bahkan sosial budaya. $^{4}$

Dalam Laporan Tahunan 2014 yang dikeluarkan oleh Wahid Institute menyebutkan bahwa Yogyakarta merupakan daerah yang menempati sebagai daerah tidak toleran, dan menempatkan Yogyakarta diperingkat kedua sebagai daerah yang tidak toleran. Dalam laporan tersebut, pada tahun 2014 tercatat ada 21 kasus intoleransi dan pelanggaran Kebebasan Beragama dan Berkeyakinan (KBB), dan jika dibandingkan dengan tahun 2013 yang hanya terdapat satu kasus maka, meningkatnya intoleransi tersebut menimbulkan banyak pertanyaan. Sedangkan diukur melalui peringkat, urusan tersebut menempatkan Jawa Barat merupakan urutan teratas yaitu 55 kasus pelanggaran. ${ }^{5}$ Beberapa kasus intoleransi yang terjadi di yogyakarta pada tahun 2018, adalah sebagai berikut:

1. Penolakan penerbitan Izin Mendirikan Bangunan (IMB) kantor sekretariat Gereja Kristen Jawa (GKJ) Klasis Gunungkidul. ${ }^{6}$ penolakan penerbitan Izin Mendirikan Bangunan (IMB) kantor sekretariat Gereja Kristen Jawa (GKJ) Klasis Gunungkidul oleh Dinas Penanaman Modal dan Perijinan Terpadu (PMPT) berakhir, setelah Pengadilan

\footnotetext{
${ }^{3}$ Laporan Tahunan The Wahid Institute, "Kebebasan Beragama/Berkeyakinan dan Intoleransi 2014

"Utang" Warisan Pemerintah Baru", Jakarta, 2014. hlm.19-20

${ }^{4}$ Ibid., hlm.20

${ }^{5}$ Bagus Takwin, dkk. "Studi tentang Intoleransi dan Radikalisme di Indonesia: Pembelajaran dari 4 Daerah, Tasikmalaya, Jogjakarta, Bojonegoro dan Kupang", International NGO Forum on Indonesia Development (INFID) di 4 Wilayah, 2016. hlm.31

${ }^{6}$ https:/ / gunungkidul.sorot.co/ berita-101035-lbh-yogyakarta-minta-dinas-segera-terbitkan-ijinpembangunan-gedung-klasis.html, Diakses pada 27 Maret, 2020
} 
Tata Usaha Negara (PTUN) Yogyakarta mengabulkan gugatan pihak klasis. Hal tersebut terkait permohonan penerbitan IMB kantor Klasis Gunungkidul pada Dinas PMPT Gunungkidul telah memiliki kepastian hukum atas penerbitannya. Hakim PTUN dalam putusannya telah menyatakan bahwa surat penolakan penerbitan IMB kantor Klasis yang dikeluarkan oleh Dinas PMPT batal dan dicabut, serta memerintahkan kepada Dinas PMPT Gunungkidul untuk memproses dan menerbitkan Izin Mendirikan Bangunan (IMB) Kantor Klasis yang diajukan oleh Badan Pelaksana Klasis. Kasus tersebut hingga 5 februari 2020 belum selesai.

2. Penolakan terhadap sedekah laut. ${ }^{7}$ Pada saat akan melaksanakan sedekah laut, dengan tiba-tiba ada dua rombongan mobil melakukan penyerangan dan mengobrak-abrik peralatan yang akan digunakan untuk sedekah laut. Kelompok tersebut bercadar dan dengan teriakan "takbir" kemudian melakukan penyerangan.

3. Pengrusakan terhadap barang-barang di PN Bantul dilakukan oleh Ormas. ${ }^{8}$ Kasus ini bermula dari ditetapkannya Ketua Pemuda Pancasila Kabupaten Bantul, Yogyakarta, Doni Bimo Saptoto, sebagai tersangka kasus persekusi oleh PN Bantul. Dia dan sejumlah anggota ormasnya, memaksa penghentian rangkaian kegiatan peringatan Hari Pers Internasional di Pusat Studi HAM Universitas Islam Indonesia, Yogyakarta pada 8 Mei 2017 lalu. Tidak terima dengan tindakan ormas tersebut, Pusham UII melaporkan pelaku kepada polisi. Eko Riyadi, Direktur Pusham UII, sebelumnya dalam persidangan menyatakan bahwa terdakwa Doni dan kawan-kawannya membongkar pameran yang telah disiapkan di kantornya. Mereka memaksa staf lembaga itu, menghentikan seluruh kegiatan terkait hari Pers Internasional.

4. Pemotongan Salib. ${ }^{9}$ Terjadi pemotongan kayu nisan berbentuk salip yang dipotong oleh warga di Pemakaman Jambon Purbayan RT 53/13, Kota Gede, Yogyakarta. Kayu nisan milik Albertus Slamet Sugihardi itu dibangun di dalam pemakaman muslim. Pada awalnya, warga disekitar sepakat jasad almarhum Albertus dimakamkan di pemakaman muslim dengan perjanjian tidak boleh ada atribut nonmuslim. Namun, ternyata pihak keluarga membuat nisan berbentuk salib sehingga dipotong oleh warga. Warga dan keluarga Albertus pun melakukan

\footnotetext{
7 https://www.liputan6.com/regional/read/3667306/saat-sedekah-laut-dirusak-gerombolan-massabercadar-di-bantul, Diakses pada 27 Maret, 2020 ${ }^{8} \mathrm{https}$ // www.voaindonesia.com/a/polisi-tangkap-anggota-ormas-pelaku-perusakanpengadilan/4459994.html, Diakses pada 28 Maret, 2020 9 https:/ / www.suara.com/news/2019/04/03/163344/salib-dipotong-hingga-tolak-sedekah-laut-4kasus-intoleransi-di-yogyakarta, Diakses pada 12 Desember, 2019
} 
musyawarah guna menghindari kesalahpahaman. Akhirnya, keluarga Albertus pun sepakat berdamai dan tidak mempermasalahkan pemotongan nisan salib di makam Albertus.

5. Warga Nonmuslim Ditolak di Pedukuhan Karet, Bantul. Seorang seniman bernama Slamet Jumiarto beserta istri dan kedua anaknya ditolak untuk bermukim di RT 08, Pedukuhan Karet, Pleret, Bantul. Alasan dari penolakan tersebut karena tinggal di wilayah itu lantaran Slamet beragama Kristen. Hal itu menyebabkan adanya kesalahpahaman yang kemudian terjadilah mediasi, hasil dari mediasi sebagian warga tidak keberatan Slamet tinggal di wilayahnya. Namun Kepala Pedukuhan Karet bersikeras menolaknya dan hanya mengizinkan Slamet tinggal selama 6 bulan. Keputusan tersebut kemudian diterima oleh Slamet dan memilih pergi berpindah tempat tinggal. Menurut Kepala Pedukuhan Karet Iswanto, keputusan penolakan dilakukan berdasarkan pada Surat Keputusan nomor 03/POKGIAT/Krt?Plt/X/2015, dimana dalam surat keputusan itu tertulis bahwa pendatang baru harus beragama Islam, sama dengan agama yang dianut oleh mayoritas penduduk. Peraturan ini pun akhirnya dicabut setelah pasca terjadi penolakan terhadap Slamet. Pencabutan aturan dilakukan pada 2 April 2019.

Kasus 2018 diatas dimulai sejak bulan Januari 2018, dimana kasus tersebut merupakan dari adanya fungsi negara yang kurang berperan. Namun dalam hasil riset yang dilakukan oleh Setara Institute menempatkan Yogyakarta berada di tengah yaitu peringkat ke 41 dari 98 kota di Indonesia. Menurut Koordinator Aliansi Nasional Bhinneka Tunggal Ika (ANBHI) DIY Agnes Dwi Rusjiati bahwa, kasus intoleransi di DIY mengalami penurunan misalnya, pada 2015 ditemukan 23 kasus, 20169 kasus, 20179 kasus dan 2018 ditemukan 10 kasus. Dan dari 10 kasus ditahun 2018, empat kasus merupakan kasus yang muncul dari tahun $2017 .{ }^{10}$

Persoalan Intoleransi beragama dan berkeyakinan yang terjadi di yogyakarta menjadi suatu fenomena yang tidak hanya menimbulkan konflik sosial horizontal dan vertikal namun, menjadikan Yogyakarta yang mempunyai slogan "daerah toleran" dan "kota pendidikan" semakin luntur. Maka, penanganan terhadap tindakan-tindakan intoleran haruslah diantisipasi dalam peraturan perundang-undangan hingga tingkat daerah.

\footnotetext{
${ }^{10} \mathrm{https}$ // jogjapolitan.harianjogja.com/read/2018/12/21/510/960243/10-kasus-intoleransibertebaran-di-jogja-sepanjang-2018., Diakses pada 27 Februari, 2020
} 


\section{Sebab-sebab Terjadinya Intoleransi di Yogyakarta}

Yogyakarta adalah daerah yang mempunyai status Istimewa dalam penyelenggaraan pemerintaan dalam kerangka negara kesatuan republik indonesia. Dengan status tersebut seharusnya Yogyakarta dapat mempertahankannya melalui perilaku masyarakatnya, pemerintahnya dan semua yang ada di Yogyakarta dengan perilaku yang baik, mengedepankan moral serta caracara yang baik.

Tanggungjawab negara untuk memastikan setiap warga negara di Yogyakarta pada khususnya, menjadi hal yang sangat penting terutama persoalan kebabasan beragama dan berkeyakinan. Kebebasan beragama dan berkeyakinan menurut Sosiolog Universitas Gadjah Mada (UGM) Arie Sutjito, frekuensi kebebasan beragama dan berkeyakinan serta perbedaan pendapat dan afiliasi semakin menunjukkan gejala disintegrasi sosial. Hal ini menurutnya karena, negara khususnya pemerintah daerah kurang efektif melindungi warga negara. ${ }^{11}$

Lebih lanjut Sujito menjelaskan bahwa, tindakan-tindakan intoleransi dipicu oleh adanya perubahan kondisi sosial diwilayah tersebut misalnya, maraknya pembangunan hotel, mall, tata kota yang tidak terkontrol, dan ruang-ruang publik yang semakin hilang. Dengan perubahanperubahan tersebut maka, masyarakat semakin pragmatis, apatis, dan keperdulian sosial semakin menipis. Maka, perlu tindakan pemerintah daerah (Gubernur, Bupati dan walikota) untuk pro-aktif dalam menangani hal-hal semacam itu.

Menanggapi laporan dari Setara Institute yang menyebutkan bahwa Yogyakarta masuk dalam 10 daerah dengan jumlah kasus pelanggaran tertinggi dalam lima tahun belakangan ini, Gubernur DIY Sri Sultan HB X menyebutkan bahwa Pemda DIY telah melakukan upaya untuk meminimalisir tindakan Intoleransi dengan menggalakkan literasi di masyarakat. Selain itu, pemda telah mengeluarkan kebijakan serta secepat mungkin menangani tindakan-tindakan intoleransi. Pananganan intoleransi sudah mulai terlihat semakin baik perkembangannya, dan yang juga perlu diketahui bahwa motif dari adanya tindakan intoleransi selalu berubah-ubah. ${ }^{12}$

\section{Kendala Yuridis dan Implementasi}

Sebagaimana dijelaskan dalam Pasal 1 angka (1) dan (2) UU No. 13 Tahun 2012 tentang Keistimewaan Daerah Istimewa Yogyakarta, bahwa daerah provinsi yogyakarta yang mempunyai keistimewaan dalam penyelenggaraan urusan pemerintahan dalam kerangka Negara Kesatuan

\footnotetext{
${ }^{11}$ https://regional.kompas.com/read/2015/01/19/16311881/Kasus.Intoleransi.DI.Yogyakarta.Dimin ta.Waspada., Diakses pada 23 Februari, 2020 12 https:/ / regional.kompas.com/read/2019/11/25/16572361/intoleransi-meningkat-di-yogyakartaini-tanggapan-sri-sultan?page=all., Diakses pada 25 Juni, 2020
} 
Republik Indonesia dan keistimewaan tersebut berdasarkan sejarah dan hak asal usul menurut UUD 1945 untuk mengatur dan mengurus kewenangan istimewa.

Sebagai daerah istimewa yang mempunyai hak untuk mengatur urusannya sendiri maka, kesejahteraan dan ketentraman masyarakat yogyakarta menjadi tanggungjawab pemerintah yogyakarta, dimana kebijakan yang diatur harus berorientasi pada kepentingan masyarakat dan pengembangan kemampuan masyarakat sebagaimana Pasal 5 ayat (3). Tata Pemerintahan dan tatanan sosial sebagaimana Pasal 5 ayat (4) menyebutkan bahwa menjamin ke-bhinnekatunggalika-an dalam kerangka Negara Kesatuan Republik Indonesia diwujudkan melalui:

1. Pengayoman dan pembimbingan masyarakat oleh pemerintahan daerah DIY;

2. Pemeliharaan dan pendayagunaan nilai-nilai musyawarah, gotong royong, solidaritas, tenggang rasa, dan "toleransi" oleh pemerintahan daerah DIY dan masyarakat DIY.

Dalam melakukan kegiatan yang berkaitan dengan pemerintahan maka, Gubernur mempunyai tugas, wewenang dan hak sehingga, segala urusan pemerintahan di DIY dapat dijalankan sesuai dengan tugas, wewenang dan hak sebagai gubernur. Adapun tugas, wewenang dan hak gubernur adalah: 
Tabel: 1

Pengaturan Ketertiban Masyarakat dan Tindak Lanjut

\begin{tabular}{|c|c|c|}
\hline & $\begin{array}{c}\text { UU No. } 13 \text { Tahun } 2012 \text { tentang } \\
\text { Keistimewaan Daerah Istimewa } \\
\text { Yogyakarta }\end{array}$ & $\begin{array}{c}\text { Peraturan Daerah No. } 1 \text { Tahun } 2018 \\
\text { tentang Kelembagaan Pemerintah } \\
\text { Daerah } \\
\text { Daerah Istimewa Yogyakarta }\end{array}$ \\
\hline & $\begin{array}{c}\text { Tugas Gubernur Berdasarkan } \\
\text { Pasal } 10 \text { ayat (1) }\end{array}$ & Tindak Lanjut \\
\hline $\begin{array}{l}\text { b. } \\
\text { c. } \\
\text { d. }\end{array}$ & $\begin{array}{l}\text { memimpin penyelenggaraan urusan } \\
\text { pemerintahan dan urusan } \\
\text { Keistimewaan berdasarkan peraturan } \\
\text { perundang-undangan, dan kebijakan } \\
\text { yang ditetapkan bersama DPRD DIY; } \\
\text { mengoordinasikan tugas satuan kerja } \\
\text { perangkat daerah dan instansi vertikal } \\
\text { di daerah; } \\
\text { memelihara ketenteraman dan } \\
\text { ketertiban masyarakat; } \\
\text { menyusun dan mengajukan rancangan } \\
\text { Perda tentang rencana pembangunan } \\
\text { jangka panjang daerah dan rencana } \\
\text { pembangunan jangka menengah daerah } \\
\text { kepada DPRD DIY untuk dibahas } \\
\text { bersama serta menyusun dan } \\
\text { menetapkan rencana kerja perangkat } \\
\text { daerah; } \\
\text { menyusun dan mengajukan rancangan } \\
\text { Perda tentang anggaran pendapatan dan } \\
\text { belanja daerah, rancangan Perda } \\
\text { tentang perubahan anggaran } \\
\text { pendapatan dan belanja daerah, dan } \\
\text { rancangan Perda tentang }\end{array}$ & $\begin{array}{l}\text { Pasal } 6 \text { ayat (2) huruf c No. } 1 \text { bahwa, "Biro } \\
\text { Bina Mental Spiritual" menjadi asisten Sekda } \\
\text { dalam penggoordinasian penyusunan } \\
\text { kebijakan administratif bidang pemberdayaan } \\
\text { sumber masyarakat. }\end{array}$ \\
\hline
\end{tabular}




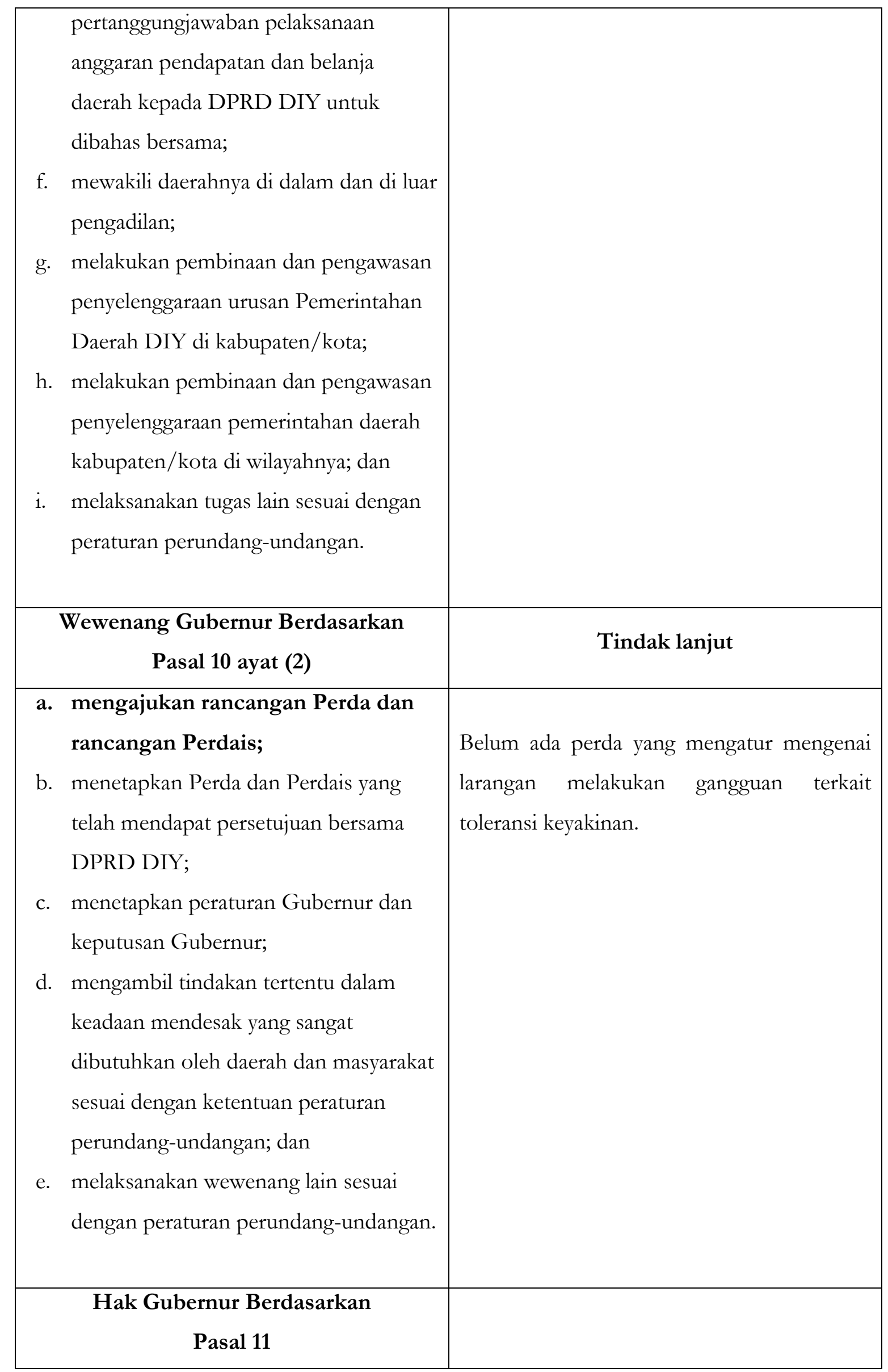




\begin{tabular}{|l|l|}
\hline a. & menyampaikan usul dan/atau pendapat \\
& kepada Pemerintah dalam rangka \\
& penyelenggaraan Kewenangan Istimewa; \\
b. & mendapatkan informasi mengenai \\
& kebijakan dan/atau informasi yang \\
& diperlukan untuk perumusan \\
& kebijakan mengenai Keistimewaan \\
& DIY; \\
c. & mengusulkan perubahan atau \\
& penggantian Perdais; dan \\
d. & mendapatkan kedudukan protokoler dan \\
& keuangan sesuai dengan ketentuan \\
& peraturan perundangundangan.
\end{tabular}

Pada huruf c UU No. 13 Tahun 2012 tentang Keistimewaan Daerah Istimewa Yogyakarta, telah menegaskan bahwa tugas dari gubernur adalah "memelihara ketenteraman dan ketertiban masyarakat". Tugas gubernur yang menyebutkan bahwa tugas gubernur adalah "memelihara ketenteraman dan ketertiban masyarakat", secara yuridis telah tersedia ruang yang dapat digunakan oleh gubernur untuk mengajukan rancangan perda dan rancangan Perdais. Sehingga, pemanfaatan ini sebenarnya dapat digunakan untuk mengatur segala sesuatu yang berhubungan dengan kepentingan masyarakat di Yogyakarta, khususnya terkait kebebasan beragama dan berkeyakinan.

Dengan demikian, gubernur dapat mengajukan perda dan perdais terkait penanganan terjadinya intoleransi di daerah istimewa yogyakarta. Untuk menyusun suatu perda dan perdais tentu, pasal 11 huruf b UU No. 13 Tahun 2012, yang menyebutkan bahwa "hak gubernur salah satunya adalah mendapatkan informasi mengenai kebijakan dan/atau informasi yang diperlukan untuk perumusan kebijakan mengenai keistimewaan”. Pasal ini menjadi dasar sebagai salah satu pijakan pemda untuk membuat suatu kebijakan yang dapat meredam situasi intoleran.

Sekalipun terdapat ketentuan mengenai posisi Biro Bina Spiritual, namun Biro tersebut posisinya sangat lemah karena menjadi bagian dari sekretaris daerah. Dalam artian, tidak

13 Parampara Praja sebagaimana Pasal 1 butir 9 Perda No. 1 Tahun 2018 tentang Kelembagaan Pemerintah Daerah Daerah Istimewa Yogyakarta, menyebutkan bahwa lembaga non struktural yang mempunyai tugas dan fungsi memberikan pertimbangan, saran dan pendapat mengenai urusan keistimewaan kepada Gubernur. 
mempunyai independensi yang dapat mempunyai kekuasaan untuk terlibat aktif dalam membentuk perda.

Dilihat dari aspek kelembagaan, dari 19 dinas (Pasal 10 Perda 1 Tahun 2018), tidak ada dinas yang khusus menangani masalah "toleransi". Padahal, jika pemda membentuk lembaga khusus yang menangani tindakan-tindakan intoleransi maka tindakan tersebut akan terkontrol secara sistematis. Lembaga sebagaimana dimaksud dapat merujuk terhadap status daerah yang telah mendapatkan status daerah istimewa.

Tidak adanya ketentuan mengenai tidak adanya "lembaga" yang mengurusi toleransi dalam Perda No. 1 tahun 2018 namun penanganan tindakan intoleransi, menunjukkan bahwa penangananan intoleransi secara kelembagaan sangatlah lemah. Padahal, salah satu dari hak Gubernur adalah mengusulkan perda. Perda tersebut sebenarnya juga bisa saja mengatur mengenai larangan adanya tindakan-tindakan intoleran di Yogyakarta.

Dilihat dari segi kelembagaan yang diatur melalui Perda No. 1 Tahun 2018, memang lembaga yang khusus menangani masalah intoleransi diperlukan sehingga, jaminan untuk menangani intoleran dilihat dari perspektif ketatanegaraan sangat lemah. Hal ini dapat dibandingkan dengan kegiatan-kegiatan lain yang mempunyai lembaga khusus misalnya, keberadaan Dinas Pariwisata yang tujuannya adalah merawat, mengembangkan dan mempromosikan wisata di yogyakarta secara kelembagaan telah diatur. Dengan majunya aspek pariwisata tentu menimbulkan perubahan sosial masyarakat yang semakin mengarah terhadap pragmatisme, yang kemudian dapat berkembang memunculkan ruang-ruang menipisnya keperdulian sosial. Mendesaknya lembaga khusus yang menangani tindakan intoleransi adalah:

1. Masih tingginya tindakan intoleransi;

Tingginya tindakan intoleransi sebagaimana laporan beberapa lembaga diatas kemudian menyebabkan urgennya hadirnya lembaga khusus yang menangani mengenai tindakan intoleransi.

2. Yogyakarta sebagai kota budaya dan kota pendidikan;

Sebagai kota budaya dan kota pendidikan, Yogyakarta menjadi kota alternatif dari berbagai daerah di Indonesia dalam mempengaruhi kondisi intelektual. Dengan demikian, pertumbuhan kalangan akademisi akan sangat memungkinkan tumbuh dari yogyarta dan mempengaruhi daerah lainnya sehingga, secara tidak langsung budaya intelektual salah satu sumbernya berasal dari yogyakarta.

3. Status Yogyakarta yang menjadi daerah istimewa; 
Status "istimewa" tentu status yang tidak semua daerah memilikinya karena banyak faktor sehingga, status tersebut juga harus didukung dengan kondisi Yogyakarta yang aman, damai, dan nyaman.

4. Kesadaran hukum masyarakat yang tidak merata. Kesadaran sebagamana dimaksud bukan hanya karena masyarkat lokal itu sendiri namun, para pendatang atau orang-orang yang bertempat tinggal di Yogyakarta (baik menetap atau sementara) yang setiap tahunnya semakin bertamah. Sehingga, antara masyarakat yang menjadi penduduk tetap dan penduduk tidak tetap tentu mempunyai kesadaran hukum yang berbeda.

Penganan konflik sosial yang terjadi di Yogyakarta mengacu terhadap Instruksi Gubernur DIY Nomor 1/INSTR/2019 tentang Pencegahan Potensi Konflik Sosial, bertujuan untuk menjaga situasi keamanan, ketentraman, ketertiban dan kedamaian di wilayah Daerah Istimewa Yogyakarta sebagai wujud tanggung jawab Pemerintah Daerah dalam memenuhi hak-hak asasi Masyarakat. Intruktsi tersebut kemudian ditujukan kepada, Bupati/Walikota se-Daerah Istimewa Yogyakarta untuk ikut mencegah adanya intoleransi di DIY. Isi dari intruksi tersebut diantaranya adalah; Pertama: Melakukan upaya-upaya pencegahan praktik diskriminasi dan menjunjung tinggi sikap saling menghormati serta menjaga kerukunan hidup beragama dan aliran kepercayaan. Kedua: Melakukan upaya-upaya pencegahan dengan merespon secara cepat dan tepat semua permasalahan di dalam masyarakat yang berpotensi menimbulkan intoleran dan/atau potensi konflik sosial, guna mencegah lebih dini tindak kekerasan.

Adapun isi instruksi Gubernur DIY Nomor 1/INSTR/2019 tentang Pencegahan Potensi Konflik Sosial: Dalam rangka menjaga situasi keamanan, ketentraman, ketertiban dan kedamaian di wilayah Daerah Istimewa Yogyakarta sebagai wujud tanggung jawab Pemerintah Daerah dalam memenuhi hak-hak asasi Masyarakat, dengan ini menginstruksikan : Kepada : Bupati/Walikota seDaerah Istimewa Yogyakarta Untuk : KESATU: Melakukan pembinaan dan pengawasan dalam rangka mewujudkan kebebasan beragama dan beribadat menurut agama dan keyakinanya, memilih pendidikan dan pengajaran, memilih pekerjaan dan bertempat tinggal. KEDUA: Melakukan upayaupaya pencegahan praktik diskriminasi dan menjunjung tinggi sikap saling menghormati serta menjaga kerukunan hidup beragama dan aliran kepercayaan.

KETIGA: Melakukan upaya-upaya pencegahan dengan merespon secara cepat dan tepat semua permasalahan di dalam masyarakat yang berpotensi menimbulkan intoleran dan/atau potensi konflik sosial, guna mencegah lebih dini tindak kekerasan. KEEMPAT: Meningkatkan efektivitas pencegahan potensi intoleran dan/atau potensi konflik sosial, secara terpadu, sesuai tugas, fungsi dan kewenangan masing-masing berdasarkan peraturan perundang-undangan. 
KELIMA: Mengambil langkah-langkah cepat,tepat, tegas dan proporsional berdasarkan peraturan perundang-undangan dan menghormati nilai-nilai hak asasi manusia untuk menghentikan segala bentuk tindak kekerasan akibat intoleran dan/atau potensi konflik sosial. KEENAM: Menyelesaikan berbagai permasalahan yang disebabkan oleh Suku, Agama, Ras, Antar Golongan (SARA) dan politik yang timbul dalam masyarakat dengan menguraikan dan menuntaskan akar masalahnya.

KETUJUH: Melakukan pembinaan dan pengawasan terhadap pelaksanaan penanganan konflik sosial sebagaimana diatur dalam Peraturan Gubernur Daerah Istimewa Yogyakarta Nomor 107 Tahun 2015 Tentang Penanaganan Konflik Sosial, kepada organisasi perangkat daerah, kepala desa sampai dengan masyarakat di lingkungan kabupaten/kota. KEDELAPAN: Segala bentuk keputusan/kebijakan agar disesuaikan dengan intruksi gubernur ini. Instruksi Gubernur ini mulai berlaku pada tanggal ditetapkan 4 April 2019.

Isi dari intruksi gubernur tersebut memang dapat meredam kondisi konflik yang terjadi di masyarakat, ini terbukti ketika terjadi tindakan intoleransi di Pleret, Bantul mengenai seorang seniman hanya diperboleh mengontrak rumah selama 6 bulan karena masalah perbedaan agama (dijelaskan pada halaman sebelumnya). Kasus tersebut yang kemudian membuat masalah semakin rumit, dan kemudian dengan adanya intruksi gubernur kemudian masalah tersebut dapat diselesaikan.

\section{E. Penutup}

Dari uraian tersebut kemudian dapat ditarik kesimpulan sebagai berikut: pertama, secara regulasi mengenai penanganan/pencegahan intoleransi perlu diperkuat melalui Peraturan Daerah DIY. Kedua, dalam Peraturan Daerah perlu dibentuk lembaga khusus yang berwenang menangani tindakan intoleransi. Ketiga, sosialisasi terhadap masyarakat mengenai larangan intoleransi perlu diperkuat. Keempat, perlu diatur mekanisme komplein untuk mempermudah masyarakat dalam mengadu.

Dengan adanya empat kesimpulan dari hasil uraian tersebut maka, dalam suatu perkembangan yang terjadi daerah perlu membuat suatu konsep agar tindakan-tindakan intoleransi tidak lagi terjadi di Yogyakarta.

\section{DAFTAR PUSTAKA}

Huda, Ni'matul. 2013. Daerah Istimewa Yogyakarta dalam Perdebatan Konstitusi dan Perundang-undangan di Indonesia”. Bandung: Nusa Media.

2014. Desentralisasi Asimetris dalam NKRI, Bandung: Nusa Media. 
Takwin, Bagus, dkk, "Studi tentang Intoleransi dan Radikalisme di Indonesia: Pembelajaran dari 4 Daerah, Tasikmalaya, Jogjakarta, Bojonegoro dan Kupang”, International NGO Forum on Indonesia Development (INFID), 2016.

Perda No. 1 Tahun 2018 tentang Kelembagaan Pemerintah Daerah Daerah Istimewa Yogyakarta.

Penetapan Presiden Nomor 1 Tahun 1965 tentang Pencegahan Penyalahgunaan dan/atau Penodaan Agama

Laporan The Wabid Institute 2014

PNPS Nomor 1 Tahun 1965

Undang-Undang Dasar NRI 1945

Undang-undang Nomor 13 tahun 2012 tentang Keistimewaan Daerah Istimewa Yogyakarta

Instruksi Gubernur DIY Nomor 1/INSTR/2019 tentang Pencegahan Potensi Konflik Sosial

Undang-undang Nomor 39 Tahun 1999 tentang Hak Asasi Manusia

Deklarasi Universal 1981

\section{Website}

https://www.suara.com/news/2019/04/03/163344/salib-dipotong-hingga-tolak-sedekah-laut-

4-kasus-intoleransi-di-yogyakarta. diakses 12/11/2019

https://gunungkidul.sorot.co/berita-101035-lbh-yogyakarta-minta-dinas-segera-terbitkan-ijin-

pembangunan-gedung-klasis.html.27/03/2020

https://www.liputan6.com/regional/read/3667306/saat-sedekah-laut-dirusak-gerombolan-

massa-bercadar-di-bantul. 27/03/2020

https://www.voaindonesia.com/a/polisi-tangkap-anggota-ormas-pelaku-perusakan-

pengadilan/4459994.html. 28/03/2020

https://www.suara.com/news/2019/04/03/163344/salib-dipotong-hingga-tolak-sedekah-laut-

4-kasus-intoleransi-di-yogyakarta. diakses 12/11/2019

https://jogjapolitan.harianjogja.com/read/2018/12/21/510/960243/10-kasus-intoleransi-

bertebaran-di-jogja-sepanjang-2018.diakses 27/02/2020

https://regional.kompas.com/read/2015/01/19/16311881/Kasus.Intoleransi.DI.Yogyakarta.Di

minta.Waspada.diakses 03/02/2020

https://regional.kompas.com/read/2019/11/25/16572361/intoleransi-meningkat-di-

yogyakarta-ini-tanggapan-sri-sultan?page $=$ all.diakses 25/06/2020 